\title{
Decision Support for New Employee Admissions with Profile Matching and Electre Methods
}

\author{
Dini Estu Sri Rahajeng ${ }^{1 *}$, Imam Husni Al Amin² \\ ${ }^{1,2}$ Informatics Engineering Study Program, Faculty of Information Technology, \\ Universitas Stikubank, Indonesia
}

\begin{abstract}
Purpose: Employee turnover at large companies is something that often occurs which can result in losses to the company. Difficulties experienced by the company in selecting prospective new employees have resulted in employees being hired not following company expectations. Because of this, we need a decision support system that can help to recommend prospective new employees who match the company's criteria.

Methods: The profile matching method is used to determine the alternative values and criteria from the aspects of personality, job aspects, attitudes, and social aspects of prospective new employees, while the Electre method is used to improve the ranking of the best prospective employees.

Result: By eliminating the alternative value $<=1$ on the line, each line is a candidate who is declared accepted with the best alternative value.

Novelty: Research on decision support systems for new employee recommendations has been done a lot, but no one has combined methods Profile Matching and Electre in one system.
\end{abstract}

Keywords: New Employee Admissions System, Profile Matching, Electre Method

Received January 2021 / Revised February 2021 / Accepted February 2021

This work is licensed under a Creative Commons Attribution 4.0 International License.

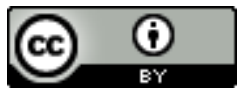

\section{INTRODUCTION}

The decision support system for hiring new employees is one of the systems that is usually used in the middle to upper-scale companies to assist companies in finding prospective employees who meet their needs. In Indonesia alone, there are enough companies that use this technology to support company performance. Even though there are still many companies that are unable to optimize this application for their company [1]. From several existing studies, some still use one method and do not optimize the results of calculating their recommendations. So that the final value obtained as a material for recommending a problem or object is less accurate. Several previous studies by [2] Explain that fuzzy logic is a method of reasoning that can be formulated without artificial processing or providing a precise assessment, Aims to apply fuzzy logic to help determine a decision regarding the evaluation and selection process for new employee recruitment.

Furthermore by [3] In a study conducted to determine student achievement at the University of Muhammadiyah Purwokerto using the Weighted Product (WP) Method, the research process determining student achievement was determined by the criteria for English language proficiency, Cumulative Achievement Index scores, and their superior potential. Then another research conducted by [4] In determining the head of the Information Engineering study program, STMIK Musi uses a decision support system with the profile matching method by looking at the results of the top-ranking order of the highest assessment results based on several aspects of the assessment that have been determined including personality, learning management, social, planning, management of facilities and infrastructure, human resource management, financial management, reporting and evaluation.

*Corresponding author.

Email addresses: diniestu40@gmail.com (Rahajeng), imam@edu.unisbank.ac.id (Amin)

DOI: $10.15294 /$ sji.v8i1.27786 
A decision support system is a system that is expected to be a solution to recommend the best choice for an organization [5]. The decision support system to recommend the recruitment of new employees was built using the Profile Matching and Electre methods. The concept of the Profile Matching method is to make a comparison between the minimum predetermined criterion value with the value of the test results conducted or called (Gap). Whereas the Electre method is a multi-criteria decision-making method based on the concept of outranking using pairwise comparisons of alternatives based on each appropriate criterion [6].

The purpose of this study is to build a decision support system using the Profile Matching method as a calculation process to determine the total value obtained from the percentage of core and secondary factors and the Electre method as a step to facilitate each company in helping the recruitment process to determine new employees, not only makes it easier but also results in more accurate decisions.

\section{METHODS}

The method in this research is the data required includes data that will enter the system in the form of job vacancy data including what positions are needed. In addition to knowing what vacancies are needed, there is also a need for criteria data for prospective employees who will fill positions in these vacancies. Job applicant data is used as an object to calculate the applicants' eligibility level to fill job vacancies required by the company. Decision Support Result Data is expected to be a recommendation for companies in selecting candidates for employees who are following the required positions. Sources of data in the manufacture of this system from data belonging to the company PT. Desnet which is on Jl. Bukit Sari - Banyumanik - Semarang City, which has conducted a selection test, accepts new employees. The research flow is explained using a Figure 1.

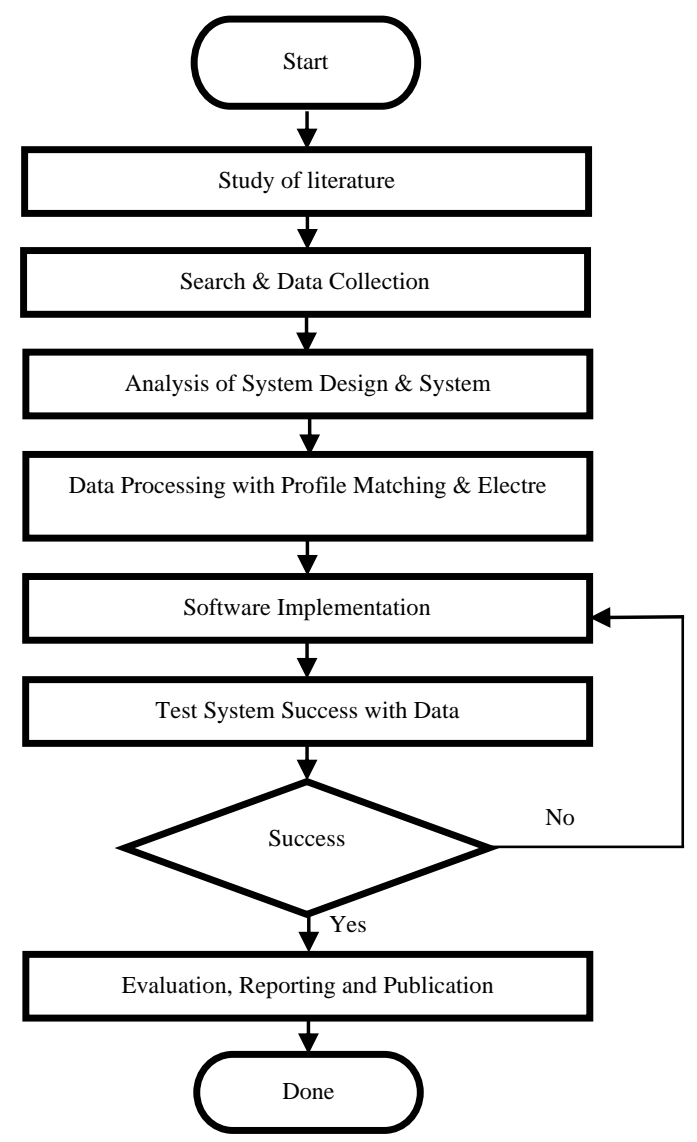

Figure 1. Research flow 


\section{Profile Matching}

Profile Matching is a process of comparing individual competencies into job competencies so that competency differences can be seen (also called gaps) [7]. The smaller the gap generated, the greater the value weight means having a greater chance for employees to occupy that position. Profile Matching is a very important process in HR management where the competencies (abilities) are required by a position are determined first. The competence of these abilities must be met by the holder or the candidate whose performance will be assessed [8].

There are several steps in calculating this profile matching method, including the selection of the core factor and the secondary factor [9]. The core factories the aspect (competency) that is the most prominent or most needed by a position that is estimated to produce optimal performance [10]. The core factor can be formulated in the following equation:

$$
N_{C F}=\frac{\sum N_{C}(i, s, p)}{\sum I_{C}}
$$

Secondary factors are items other than the aspects that exist in the core factor or can also be referred to as supporting factors[10]. The secondary factor can be written in the following formula:

$$
N_{S F}=\frac{\sum N_{S}(i, s, p)}{\sum I_{S}}
$$

\section{Electre}

Decision-makers can include a variety of quantitative and qualitative criteria into the decision-making process through Elimination And Choice Translation Reality (ELECTRE), which is an optimizationoriented mathematical programming method, weighting criteria according to objectives, which defines the optimal alternative by collecting these weight[11].

The elimination and Choice Translation Reality (ELECTRE) method was introduced by Roy (1966), who used a comprehensive evaluation approach by trying to rank the number of each alternative described on several criteria [12]. Electre starts from forming the pairwise comparison of each alternative in each criterion (xij). This value of $\mathrm{X}$ must be normalized to a comparable scale (rij):

$$
r_{i j}=\frac{x_{i j}}{\sqrt{\sum_{j=1}^{m} x_{i j}^{2}}} ; i=1,2, \ldots, n
$$

where $i=1,2, \ldots, m$; and $j=1,2, \ldots, n$; in this case, $n$ is the number of alternatives and $m$ is the number of criteria

Furthermore, the decision-maker must give an importance factor (weight) to each criterion that expresses its relative importance $(\mathrm{wj})$

$$
W=(w 1, w 2, \ldots, w n)
$$

with the total number of $\mathrm{W}$ values equal to 1 , or:

$$
\sum_{j=1}^{n} w_{j}=1
$$

This weight is then multiplied by the pairwise comparison matrix to form a matrix V:

$$
v i j=w j x i j
$$


The concordance index and discordance index for each alternative pair are done by estimating the ranking relation. For each alternative view $\mathrm{Ak}$ and $\mathrm{Ai}(\mathrm{k}, \mathrm{l}=1,2, \ldots, \mathrm{m}$; and $\mathrm{k} 1 \mathrm{l})$, the decision matrix for criterion $\mathrm{j}$ is divided into 2 subsets. First, the set of concordance index $\{\mathrm{Ckl}\}$ shows the sum of the criterion weights which alternative $\mathrm{Ak}$ is better than alternative $\mathrm{Al}$

$$
\begin{gathered}
C_{k l}=\left\{j \mid v_{k j} \geq v_{b j}\right\} \\
\text { where } \mathrm{j}=1,2, \ldots, \mathrm{n} ;
\end{gathered}
$$

Second, the set discordance index $\{\mathrm{dkl}\}$ is given as:

$$
D_{k l}=\left\{j \mid v_{k j}<v_{b j}\right\}
$$

where $\mathrm{j}=1,2, \ldots, \mathrm{n}$;

The Concordance Matrix (C) contains the elements calculated from the concordance index and relates to the attribute weights, namely:

$$
c_{k l}=\sum_{j \in C_{k}} w_{j}
$$

The matrices can be constructed with the help of a threshold value, $c$. The value of $\mathrm{C}$ can be obtained by the equation:

$$
\underline{c}=\frac{\sum_{k=1}^{m} \sum_{l=1}^{m} C_{k l}}{m(m-1)}
$$

The alternative Ak can have a chance of dominating Al, if the concordance index ckl exceeds the threshold c:

$$
C k l>=c
$$

and the elements of the dominant concordance matrix $\mathrm{F}$ are defined as:

$$
f_{k l}=\left\{\begin{array}{lll}
1 & , j i k a & c_{k l} \geq \underline{c} \\
0 & , j i k a & c_{k l}<\underline{c}
\end{array}\right.
$$

The same is true for the dominant discordance matrix $G$ with a threshold of $d$. The value of $d$ can be obtained by equations

$$
\underline{d}=\frac{\sum_{k=1}^{m} \sum_{l=1}^{m} d_{k l}}{m(m-1)}
$$

and the elements of the dominant discordance matrix $\mathrm{G}$ are specified as

$$
g_{k l}= \begin{cases}1, \text { Jika } & \overrightarrow{d_{k l} \geq d} \\ 0, \text { Jika } & \mathrm{d}_{\mathrm{kl}}<\mathrm{d}\end{cases}
$$

Aggregation of dominant matrices (E) showing the partial preference order of the alternatives is obtained by the equation:

$$
e k l=f k l \times g k l
$$

If $\mathrm{ekl}=1$; then it indicates that alternative $\mathrm{Ak}$ is preferred over alternative $\mathrm{Al}$. 


\section{Decision support systems (DSS)}

Decision Support Systems (abbreviated as DSS) are part of computer-based information systems, including knowledge-based systems (knowledge management) that are used to support decision making in a corporate organization or educational institution [10]. According to Moore and Chang, a decision support system can be described as a system capable of supporting data analysis and decision modeling, decision-oriented, future planning orientation, and used at unusual times [13].

The activity of designing a decision support system is an activity to find, develop and analyze various alternative actions that are possible to take. This design stage includes developing and evaluating a series of alternative activities. Meanwhile, the activity of selecting and studying is used to select a certain set of actions from several available ones and to make an assessment of the actions that have been selected. Decision support systems are designed to support all stages of decision making starting from identifying problems, selecting relevant data, and determining the approach used in the decision-making process to evaluating the selection of alternatives [14].

\section{GAP mapping}

The GAP mapping referred to in this discussion is the difference in criteria that a person has with the criteria that the user wants according to the aspect of assessment [15]. The formula for the GAP mapping can be seen in equation (1). GAP = Individual criteria - Desired criteria (1) Meanwhile, other GAP calculations that occur in each aspect have different calculations.

a. Weight Value Determination

After the GAP mapping has been carried out, the results of the mapping are given a weighted value with a reference weighted value table, as seen in Table 1.

Table 1 . Weighted value

\begin{tabular}{ccc}
\hline & Weighted Value & Information \\
\hline 0 & 5 & No Difference \\
1 & 4.5 & Value Exceeds 1 Level \\
-1 & 4 & Less Value 1 Level \\
2 & 3.5 & Value Exceeds 2 levels \\
-2 & 3 & Less Value 2 Levels \\
3 & 2.5 & Over 3 Levels of Value \\
-3 & 2 & Less Value 4 Levels \\
4 & 1.5 & More Value 4 Levels \\
-4 & 1 & Less Value 4 Levels \\
\hline
\end{tabular}

b. Attribute Assessment Criteria

There are several steps in calculating the decision support process for the Profile Matching method. The first thing is to determine the criteria attributes that will be used as the base for this decision support process. In this study, there are four criteria selected as criteria in the recruitment process. The criteria are shown using Table 2. 
Table 2. Attribute assessment criteria

\begin{tabular}{|c|c|c|c|c|}
\hline $\begin{array}{l}\text { Criteria } \\
\text { Table }\end{array}$ & $\begin{array}{l}\text { Personality aspects } \\
\text { (weight } 30 \text {, core factor } \\
\text { comparison: secondary } \\
\text { factor }=65 \%: 35 \% \text { ) }\end{array}$ & $\begin{array}{l}\text { Job Aspects (weight } \\
20 \% \text {, comparison to } \\
\text { core factor: } \\
\text { secondary factor = } \\
70 \%: 30 \% \text { ) }\end{array}$ & $\begin{array}{l}\text { Attitude Aspect } \\
\text { (weight } 40 \% \text {, } \\
\text { comparison to } \\
\text { core factor: } \\
\text { secondary factor = } \\
55 \%: 45 \% \text { ) }\end{array}$ & $\begin{array}{l}\text { Social Aspects } \\
\text { (weight } 10 \%, \\
\text { comparison of } \\
\text { core factor: } \\
\text { secondary factor }= \\
55 \%: 45 \% \text { ) }\end{array}$ \\
\hline & $\begin{array}{l}\text { 1. Intellect Ability, } \\
\text { 2. Ability to Convey } \\
\text { Ideas, } \\
\text { 3. Ability to Think, } \\
\text { 4. Ability to Provide } \\
\text { Solutions, } \\
\text { 5. Concentration, } \\
\text { 6. Practical Logic, } \\
\text { 7. Flexibility in } \\
\text { Thinking, } \\
\text { 8. Creativity and } \\
\text { Imagination, } \\
\text { 9. Troubleshooting } \\
\text { Ability, } \\
\text { 10. Potential Intelligence. }\end{array}$ & $\begin{array}{l}\text { 1. Physical } \\
\text { Strength at } \\
\text { work } \\
\text { 2. Carefulness and } \\
\text { responsibility } \\
\text { 3. Be careful } \\
\text { 4. Emotion } \\
\text { Control } \\
\text { 5. Motivation at } \\
\text { Work } \\
\text { 6. Planning } \\
\text { Ability }\end{array}$ & $\begin{array}{l}\text { 1. Leadership } \\
\text { 2. Ability to } \\
\text { Influence / } \\
\text { Seduce } \\
\text { 3. Determination } \\
\text { 4. Ability to meet } \\
\text { targets }\end{array}$ & 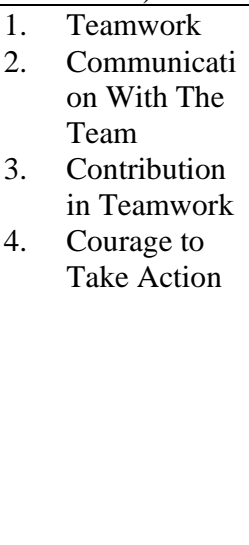 \\
\hline
\end{tabular}

\section{RESULTS AND DISCUSSION}

Based on the results of the data obtained through the selection process of new employee admissions at PT. Desnet and profile matching calculation of GAP values that have been done. Then the next step is to calculate the total value of the core factor and secondary factor, the results of the calculation are shown in Table 3. Calculated using the equation.

$$
x \cdot N_{C F}(i, s, p)+y \cdot N_{S F}(i, s, p)=N(i, s, p)
$$

Table 3. Table of aspects of assessment of prospective new employees

\begin{tabular}{llllll}
\hline \multirow{2}{*}{ No. } & \multirow{2}{*}{ Name_Id } & \multicolumn{4}{c}{ CRITERIA } \\
\cline { 3 - 6 } & & $\mathrm{C} 1$ & $\mathrm{C} 2$ & $\mathrm{C} 3$ & C4 \\
\hline 1 & Desnet_0001 & 4.02290 & 3.45000 & 4.20000 & 4.20000 \\
2 & Desnet_0002 & 4.45625 & 3.21250 & 5.00000 & 5.00000 \\
3 & Desnet_0003 & 4.17500 & 3.01250 & 4.61250 & 4.61250 \\
4 & Desnet_0004 & 3.93540 & 3.41250 & 4.50000 & 4.50000 \\
\hline
\end{tabular}

From the results of these calculations, the normalization process is carried out into the Electre method by still using an alternative value from the same as the profile matching method and given the weight value. With the calculation results shown using Table 4.

Table 4. Normalizing the electre method

\begin{tabular}{clllll}
\hline \multirow{2}{*}{ No. } & Name_Id & \multicolumn{4}{c}{ CRITERIA } \\
\cline { 3 - 6 } & & C1 & C2 & C3 & C4 \\
\hline 1 & Desnet_0001 & 0.4880 & 0.5308 & 0.4578 & 0.4578 \\
2 & Desnet_0002 & 0.5406 & 0.4942 & 0.5450 & 0.5450 \\
3 & Desnet_0003 & 0.5064 & 0.4635 & 0.5028 & 0.5028 \\
4 & Desnet_0004 & 0.4773 & 0.5250 & 0.4905 & 0.4905 \\
\hline Weight / W & & 2 & 3 & 4 & 1 \\
\hline
\end{tabular}

Then the data is calculated using the weight value (W), with the results calculated using Table 5 . 
Table 5. Weighting results for each criterion

\begin{tabular}{llllll}
\hline \multirow{2}{*}{ No. } & Name_Id & \multicolumn{4}{c}{ CRITERIA } \\
\cline { 3 - 6 } & & $\mathrm{C} 1$ & $\mathrm{C} 2$ & $\mathrm{C} 3$ & $\mathrm{C} 4$ \\
\hline 1 & Desnet_0001 & 0.9760 & 1.5924 & 1.8132 & 0.4578 \\
2 & Desnet_0002 & 1.0812 & 1.4826 & 2.1800 & 0.5450 \\
3 & Desnet_0003 & 1.0128 & 1.3905 & 2.0112 & 0.5028 \\
4 & Desnet_0004 & 0.9546 & 1.5750 & 1.9620 & 0.4905 \\
\hline
\end{tabular}

After getting the weight calculation value results for each criterion, the next step is to determine the concordance and discordance numbers with the calculation results in Table 6 and Table 7.

Table 6. Result of concordance value

\begin{tabular}{rrrrrrrr}
\hline \multirow{2}{*}{ No. } & Name_Id & \multicolumn{5}{c}{ CRITERIA } \\
\cline { 3 - 7 } & & $\mathrm{C} 1$ & $\mathrm{C} 2$ & $\mathrm{C} 3$ & $\mathrm{C} 4$ \\
\hline 1 & Desnet_0001 & - & 3 & 3 & 3 \\
2 & Desnet_0002 & 7 & - & 10 & 5 \\
3 & Desnet_0003 & 7 & 0 & - & 5 \\
4 & Desnet_0004 & 7 & 5 & 5 & - \\
\hline
\end{tabular}

Table 7. Result of discordance value

\begin{tabular}{rrrcccc}
\hline \multirow{2}{*}{ No. } & Name_Id & \multicolumn{5}{c}{ CRITERIA } \\
\cline { 3 - 7 } & & C1 & C2 & C3 & C4 \\
\hline 1 & Desnet_0001 & - & 0 & 0.8915 & 0 \\
2 & Desnet_0002 & 0.3148 & - & 0 & 0 \\
3 & Desnet_0003 & 0 & 0 & - & 0 \\
4 & Desnet_0004 & 0.0178 & 0.1496 & 0.0522 & - \\
\hline
\end{tabular}

If there is a result of the concordance value. then it can be found the threshold value in table 6 with calculations with the following equation

$$
\mathrm{C}_{\mathrm{ij}} \geq \subseteq
$$

So that the following results are obtained:

$\mathrm{C}=(3+3+3+7+10+5+7+0+5+7+5+5) /(4(4-1)=60 / 12=5$

Then the threshold value from table 6 is 5 . Comparisons are made if the matrix value is greater than or equal to the threshold value, then it is given a value of 1 , if the matrix value is below the threshold value then it is given a value. The calculation results are shown in Table 8.

Table 8. Threshold concordance value

\begin{tabular}{rrrrrrrr}
\hline \multirow{2}{*}{ No. } & & \multicolumn{5}{c}{ CRITERIA } \\
\cline { 3 - 7 } & & C1 & & C2 & C3 & C4 IId \\
\hline 1 & Desnet_0001 & - & 0 & 0 & 0 \\
2 & Desnet_0002 & 1 & - & 1 & 1 \\
3 & Desnet_0003 & 1 & 0 & - & 1 \\
4 & Desnet_0004 & 1 & 1 & 1 & - \\
\hline
\end{tabular}

If there are already results from the discordance value. then you can find the threshold value in table 7 by calculating the following equation: 


$$
\begin{aligned}
& G_{i j}=1 \text { if } G_{i j} \geq \subseteq \\
& 0 \text { if } G_{i j} \leq \subseteq
\end{aligned}
$$

So that the following results are obtained:

$\mathrm{D}=(0+0.8915+0+0.3148+0+0+0+0+0+0.0178+0.2496+0.0522) /(4(4-1))=1.5259 / 12=$ 0.1572

Then the threshold value from Table 7 is 0.1572 . Comparisons will be given a value of 1 if the value of the matrix value is greater than or equal to the threshold value and will be given a value of 0 if the value of the matrix value is smaller than the threshold value, as shown in Table 9.

Table 9. Threshold discordance value

\begin{tabular}{llllll}
\hline \multirow{2}{*}{ No. } & Name_Id & \multicolumn{4}{c}{ CRITERIA } \\
\cline { 3 - 6 } & & C1 & C2 & C3 & C4 \\
\hline 1 & Desnet_0001 & - & 0 & 1 & 0 \\
2 & Desnet_0002 & 1 & - & 0 & 0 \\
3 & Desnet_0003 & 0 & 0 & - & 0 \\
4 & Desnet_0004 & 0 & 0 & 0 & - \\
\hline
\end{tabular}

After getting the results of each concordance and discordance threshold value. We can do a ranking by looking for the dominant aggregate value using the following equation

$$
e_{k l}=f_{k l} \times g_{k l}
$$

With the calculation results are shown in Table 10.

Table 10. Rank /aggregate dominant

\begin{tabular}{llllll}
\hline \multirow{2}{*}{ No. } & Name_Id & \multicolumn{4}{c}{ CRITERIA } \\
\cline { 3 - 6 } & & C1 & C2 & C3 & C4 \\
\hline 1 & Desnet_0001 & - & 0 & 0 & 0 \\
2 & Desnet_0002 & 1 & - & 0 & 0 \\
3 & Desnet_0003 & 0 & 0 & - & 0 \\
4 & Desnet_0004 & 0 & 0 & 0 & - \\
\hline
\end{tabular}

Table 10 provides the order of choice for each alternative, that is if $\mathrm{Ckl}=1$, then the $\mathrm{Ck}$ alternative is a better alternative than $\mathrm{Cl}$. Thus, the rows in Table 10 that have the least amount of $\mathrm{Ekl}=1$ can be eliminated. Thus the first, third, and fourth rows can be eliminated, and the second row remains. The value of $\mathrm{C} 21=1$ indicates that the second alternative is better than the first, third, and fourth alternatives. So that the decision-maker will take the second alternative, or it can be said that the Candidate with Name_Id Desnet_002 is the best alternative.

\section{CONCLUSION}

Decision support systems have been proven to make it easier for companies to find recommendations for the best prospective employees based on given criteria. This decision support system can reduce company errors in assessing prospective new employees. The profile matching method is very suitable for providing valuable recommendations for several variables. In the case of the decision support system for recruiting new employees, In addition to using profile matching, a decision support system will produce a more significant and effective output value when combined with the Electre method. This is because the Electre method has a complex and detailed calculation algorithm so that the assessment of prospective new employees can produce a more accurate value. 


\section{REFERENCES}

[1] H. Wasiati and D. Wijayanti, "Sistem Pendukung Keputusan Penentuan Kelayakan Calon Tenaga Kerja Indonesia Menggunakan Metode Naive Bayes (Studi Kasus: Di P.T. Karyatama Mitra Sejati Yogyakarta)," IJNS - Indones. J. Netw. Secur., vol. 3, no. 2, pp. 45-51, 2014.

[2] A. Golec and E. Kahya, "A Fuzzy Model for Competency-based Employee Evaluation and Selection," Comput. Ind. Eng., vol. 5, pp. 143-161, 2007.

[3] H. Mustafidah and N. H. Hadyan, "Mahasiswa Berprestasi di Universitas Muhammadiyah Purwokerto Menggunakan Metode Weighted Product (WP)," JUITA, vol. 5, no. 1, pp. 51-61, 2017.

[4] A. A. T. Susilo, "Penerapan Metode Profile Matching pada Sistem Pendukung Keputusan Pemilihan Ketua Program Studi (Studi Kasus: Program Studi Teknik Informatika STMIK Musi Rawas)," JUITA, vol. 5, no. 2, pp. 87-93, 2017.

[5] P. J. Scott et al., "A Review of Measurement Practice in Studies of Clinical Decision Support Systems 1998-2017,” J. Am. Med. Informatics Assoc., vol. 26, no. 10, pp. 1120-1128, 2019.

[6] Akmaludin, M. Badrul, L. Marlinda, S. Dalis, Sidik, and B. Santoso, "The Employee Promotion Base on Specification Job's Performance Using: MCDM, AHP, and ELECTRE Method,” 2018.

[7] A. O. P. Sahureka, "Decision Support Systems in the Placement of Electronic Officers of Indonesian Navy with Profile Matching Method," Int. J. Eng. Res. Technol., vol. 6, no. 01, pp. 458-465, 2017.

[8] C. H. Primasari, R. Wardoyo, and A. K. Sari, "Integrated AHP, Profile Matching, and TOPSIS for Selecting Type of Goats Based on Environmental and Financial Criteria," Int. J. Adv. Intell. Informatics, vol. 4, no. 1, pp. 28-39, 2018.

[9] Safrizal, L. Tanti, R. Puspasari, and B. Triandi, "Employee Performance Assessment with Profile Matching Method," in 6th International Conference on Cyber and IT Service Management (CITSM 2018), 2019, pp. 1-6.

[10] Soleman, "Decision Support System for Employee Candidate Selection using AHP and PM Methods," IJACSA, vol. 10, no. 11, pp. 1-12, 2019.

[11] A. Yanie et al., "Web Based Application for Decision Support System with ELECTRE Method," J. Phys. Conf. Ser., vol. 1028, no. 1, 2018.

[12] S. Sadat, S. Hossein, and R. Hajiagha, "Multicriteria Group Decision Making with ELECTRE III Method Based on Interval-valued Intuitionistic Fuzzy Information," Appl. Math. Model., vol. 40, no. 2, pp. 1554-1564, 2016.

[13] M. H. I. Fahmi and I. H. Al Amin, "Best Products with TOPSIS Method and Sales Forecasting with Weighted," J. Appl. Informatics Comput., vol. 4, no. 2, pp. 116-123, 2020.

[14] E. Sugiyarti, K. A. Jasmi, B. Bushrah, M. Huda, S. K, and A. Maseleno, "Decision Support System of Scholarship Grantee Selection using Data Mining Decision Support System of Scholarship Grantee," Int. J. Pure Appl. Math., vol. 119, no. 15, pp. 2239-2248, 2018.

[15] J. K. Kazak, J. Chruscinski, and S. Szewranski, "The Development of A Novel Decision Support System for the Location of Green Infrastructure for Stormwater Management," Sustainability, vol. 10, no. 12, p. 4388, 2018. 